\title{
FAKTOR MATERNAL YANG MEMPENGARUHI KEJADIAN BERAT BAYI LAHIR RENDAH (BBLR) DI KOTA TEGAL
}

\author{
Umriaty $^{1}$, Juhrotun Nisa ${ }^{2}$ \\ email : umri.midwife@gmail.com \\ Diploma III Kebidanan Politeknik Harapan Bersama
}

\begin{abstract}
Abstrak
Menurut data WHO tahun 2015 jumlah BBLR di Indonesia berada di peringkat sembilan dunia dengan persentase BBLR lebih dari 15,5\% dari kelahiran bayi. Bayi yang lahir dengan berat badan kurang dari 2500 gram mempunyai resiko mengalami komplikasi. Keberlanjutan kehidupan bayi yang lahir dengan berat rendah juga sangat tergantung dari keadaan ekonomi, Pendidikan orang tua dan perawatan pasca bayi lahir. Penelitian ini adalah penelitian survey analitik. Rancangan penelitian yang digunakan adalah case control yaitu penelitian melibatkan kelompok kasus yaitu bayi BBLR yang berjumlah 32 dan bayi yang lahir dengan berat lahir normal sebagai kelompok kontrol yang berjumlah 32. Variabel faktor ibu yang diteliti pada penelitian ini adalah umur ibu, paritas, jarak kehamilan, status gizi ibu, anemia dalam kehamilan, pre eklampsi, dan riwayat berat lahir rendah pada kehamilan sebelumnya. Penelitian ini dilakukan pada bulan Oktober sampai dengan Desember 2017. Hasil penelitian menunjukkan bahwa sebagian besar bayi lahir pada umur ibu usia tidak beresiko 68, 8 \%, paritas Pirmi/multigravida 90,6\%, jarak kehamilan $\geq 2$ tahun 84,6\%, ibu hamil tidak KEK 68,8, anemia dalam kehamilan $50 \%$. Hasil analisis uji hubungan dengan Chi Square dan alpha 0,05 didapatkan 2 variabel mempunyai hubungan yang bermakna yaitu status gizi ( $p$ value 0,023), dan Anemia dalam kehamilan ( $p$ value 0,012).
\end{abstract}

Kata kunci : faktor maternal, Bayi Berat Lahir Rendah

\begin{abstract}
According to WHO data in 201, the number of Low Birth Weight (LBW) of Indonesia is ranked ninth in the world with the percentage of LBW more than $15.5 \%$ of babies born. Babies born with weight less than 2500 grams have a risk of complications. The sustainability of a low birth weight baby's life is also highly based on the state of the economy, parental education and postnatal care.This research is an analytic survey research. The design of the research used was case control, the study involved case groups of 32 LBW infants and babies born with normal birth weight as a control group of 32. Maternal factor variables studied in this study were maternal age, parity, gestational distance, maternal nutritional status, anemia in pregnancy, pre-eclampsia, and a history of low birth weight in previous pregnancies. This study was conducted during October to December 2017. The results showed that most of the babies born at the age of the mother were not at risk 68,8\%, Primi / multigravida 90.6\%, the distance of pregnancy $\geq 2$ years $84.6 \%$, pregnant women not KEK 68.8 , anemia in pregnancy $50 \%$. Result of analysis of test of correlation with Chi Square and alpha 0,05 got 2 variables have significant relationship that is nutrition status ( $p$ value 0,023), and Anemia in pregnancy ( $p$ value 0,012).
\end{abstract}

Keyword : maternal factor, Low Birth Weight 


\section{PENDAhuluan}

Angka Kematian Bayi (AKB) atau Infant Mortality Rate merupakan salah satu indikator yang biasa digunakan untuk menentukan derajat kesehatan masyarakat terutama pada kesehatan ibu dan anak. AKB dihitung dari jumlah bayi yang meninggal pada fase setelah lahir sampai dengan usia 1 tahun dibagi 1.000 kelahiran hidup.

Data dari Kementerian Kesehatan RI adanya penurunan Angka Kematian Bayi yaitu pada SDKI tahun 2012 sebesar 32/1000 Kelahiran Hidup dan menurun lagi pada tahun 2015 yaitu sebesar 22,23/1000 Kelahiran Hidup. Angka Kematian Bayi sampai dengan tahun 2012 terlihat pada gambar berikut ini (Kemenkes RI, 2016).

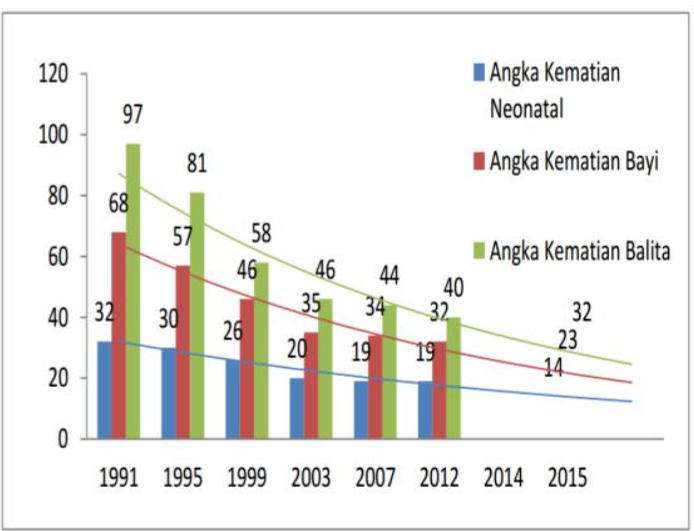

Sumber: Ditjen Gizi dan KIA, Kemenkes RI, 2015

Gambar 1. Tren Angka Kematian Bayi

Keikutsertaan pemerintah dalam program SDGs (Sustanable Development Goals) untuk melanjutkan program sebelumya yaitu MDGs (Millenium Development Goals) merupakan upaya untuk mendorong pengurangan Angka Kematian Bayi di Indonesia. Dalam salah satu tujuan SDGs adalah mengakhiri kematian bayi dan balita, mengurangi sepertiga kematian prematur akibat penyakit tidak menular melalui pencegahan dan perawatan.

Bayi Berat Lahir Rendah (BBLR) ialah bayi baru lahir yang berat badannya saat lahir kurang dari 2500 gram. BBLR tidak hanya dapat terjadi pada bayi prematur, tapi juga pada bayi cukup bulan yang mengalami hambatan pertumbuhan selama kehamilan.

Menurut data WHO tahun 2015 jumlah BBLR di Indonesia berada di peringkat sembilan dunia dengan persentase BBLR lebih dari $15,5 \%$ dari kelahiran bayi. Bayi yang lahir dengan berat badan kurang dari 2500 gram mempunyai resiko mengalami komplikasi. Keberlanjutan kehidupan bayi yang lahir dengan berat rendah juga sangat tergantung dari keadaan ekonomi, Pendidikan orang tua dan perawatan pasca bayi lahir (Kemenkes RI, 2015).

BBLR merupakan salah penyumbang terhadap Angka Kematian Bayi (AKB). Pada BBLR dengan disertai dengan prematuritas terjadi ketidakmatangan sistem organ yang berdampak serius terhadap kemampuan bayi untuk bertahan hidup. Masalah pada BBLR yang sering terjadi adalah gangguan padasystem pernafasan,susunan saraf pusat, kardiovaskuler, gastrointestinal dan masalah ginjal. Sampai dengan saat ini BBLR masih menjadi salah satu penyebab kematian pada bayi baru lahir (Maryunani, 2009).

Data yang didapatkan dari Dinas Kesehatan Kota Tegal, jumlah BBLR di Kota Tegal pada tahun 2015 yaitu sebanyak 239 $(5,46 \%)$ dari total 4374 kelahiran. Angka yang tidak jauh berbeda juga ditemukanpada tahun 2016yaitu sebanyak 234 BBLR (5,45 $\%)$ dari total 4293 kelahiran.

Tujuan penelitian ini adalah untuk mengetahui faktor maternal apa saja yang dapat mempengaruhi terjadinya Berat Bayi Lahir Rendah (BBLR) di Kota Tegal yang terdiri dari faktor umur ibu, paritas, jarak kehamilan, status gizi, status anemia, riwayat Pre Eklampsi, dan Riwayat BBLR pada kehamilan sebelumnya.

\section{METODE PENELITIAN}

Penelitian ini mempunyai ruang lingkup bayi baru lahir khususnya adalah bayi yang lahir dengan berat badan rendah $(<2500$ gram). Penelitian ini merupakan penelitian survey analitik yaitu penelitian yang mencoba menggali bagaimana dan mengapa kasus BBLR terjadi dan dihubungkan dengan faktorfaktor bawaan yang berasal dari ibu. Rancangan penelitian yang digunakan adalah case control yaitu penelitian melibatkan kelompok kasus yaitu bayi BBLR dan bayi yang lahir dengan berat lahir normal sebagai kelompok kontrol. Data yang digunakan adalah data saat kehamilan pada ibu yang melahirkan BBLR. Instrumen yang digunakan adalah cheklist yang terdiri dari data tentang umur kehamilan saat melahirkan, umur ibu, berat badan bayi lahir, jarak kehamilan saat 
ibu dengan kehamilan sebelumnya, status gizi, kadar Hemoglobin, riwayat Pre Eklampsi dan riwayat BBLR pada kehamilan sebelumnya.

Penelitian ini dilakukan selama bulan Oktober sampai Desember 2017. Selama rentang waktu tersebut ibu-ibu yang melahirkan Bayi BBLR dijadikan kelompok kasus. Sedangkan ibu - ibu yang melahirkan bayi berat lahir normal dijadikan sebagai kelompok kontrol, selanjutnya dilakukan pengumpulan data terkait faktor resiko pada ibu yang berhubungan dengan kejadian
BBLR. Penelitian pada kedua kelompok tersebut dilakukan di 2 wilayah Puskesmas di Kota Tegal yang terdiri dari Puskesmas Margadana, dan Tegal Selatan.

\section{HASIL DAN PEMBAHASAN}

\section{Hasil}

Berikut adalah penyajian hasil penelitian yang merupakan karakteristik dari responden.

Tabel 1. Distribusi Frekuensi Gambaran Karakteristik Responden

\begin{tabular}{lcc}
\hline \multicolumn{1}{c}{ Karakteristik } & Jumlah & Prosentase \\
\hline Umur Ibu & & \\
$\quad$ Beresiko (<20 thn dan > 35 tahun) & 20 & 31,2 \\
$\quad$ Tidak Beresiko (20 - 35 tahun) & 44 & 68,8 \\
Paritas & & \\
$\quad$ Grandemultipara & 6 & 9,4 \\
$\quad$ Primi/Multipara & 58 & 90,6 \\
Jarak Kehamilan & & \\
$\quad$ 2 Tahun & 6 & 15,4 \\
$\quad$ 2 Tahun & 33 & 84,6 \\
Status Gizi & & \\
$\quad$ KEK & 20 & 31,2 \\
$\quad$ Tidak KEK & 44 & 68,8 \\
Status Anemia & & \\
$\quad$ Anemia & 32 & 50,0 \\
$\quad$ Tidak Anemia & 32 & 50,0 \\
Riwayat Pre Eklampsi & & \\
$\quad$ Pre Eklampsi & & 12,5 \\
$\quad$ Tidak Pre Eklampsi & 8 & 87,5 \\
Riwayat BBLR & 58 & \\
$\quad$ Ada Riwayat & & 7,7 \\
$\quad$ Tidak Ada Riwayat & 3 & 92,3 \\
\hline
\end{tabular}

Hasil penelitian pada tabel 1 terlihat bahwa sebagian besar responden melahirkan pada umur tidak beresiko $(20-35)$ tahun yaitu sebanyak 44 responden $(68,8 \%)$, merupakan kehamilan primi/multigravida sebanyak 58 responden $(90,6 \%)$, dengan jarak kehamilan $\geq 2$ tahun sebanyak 33 responden $(84,6 \%)$, status gizi tidak KEK sebanyak 44 responden $(68,8 \%)$, terjadi anemia dalam kehamilan sebanyak 32 responden $(50,0 \%)$, tidak terjadi
Pre Eklampsi dalam kehamilan sebanyak 58 responden $(87,5 \%)$, dan responden yang tidak mempunyai riwayat BBLR pada kehamilan sebelumnya yaitu sebanyak 36 responden $(92,3 \%)$. Hubungan antara variabel bebas dengan variabel terikat dapat dilihat pada tabel berikut ini. 
Tabel 2. Tabel Silang Variabel Bebas dan Variabel Terikat

\begin{tabular}{|c|c|c|c|c|c|c|}
\hline \multirow[t]{2}{*}{ Faktor Resiko } & \multicolumn{2}{|c|}{ BBLR } & \multicolumn{2}{|c|}{$\begin{array}{l}\text { Berat Lahir } \\
\text { Normal }\end{array}$} & \multirow[t]{2}{*}{$P$ value } & \multirow[t]{2}{*}{ OR } \\
\hline & $\mathrm{f}$ & $\%$ & $\mathrm{f}$ & $\%$ & & \\
\hline \multicolumn{7}{|l|}{ Umur Ibu } \\
\hline $\begin{array}{l}\text { Beresiko } \\
(<20 \text { dan }>35 \text { tahun })\end{array}$ & 11 & 55 & 9 & 45 & \multirow[b]{2}{*}{0,590} & \multirow[b]{2}{*}{1,339} \\
\hline $\begin{array}{l}\text { Tidak Beresiko } \\
(20-35 \text { tahun })\end{array}$ & 21 & 47,7 & 23 & 52,2 & & \\
\hline \multicolumn{7}{|l|}{ Paritas } \\
\hline Grande & 2 & 33,3 & 4 & 66,7 & \multirow{2}{*}{0,672} & \multirow{2}{*}{0,462} \\
\hline Primi/multi & 30 & 51,7 & 28 & 48,3 & & \\
\hline \multicolumn{7}{|l|}{ Jarak Kehamilan } \\
\hline $\begin{array}{l}<2 \text { Tahun } \\
>2 \text { Tahun }\end{array}$ & $\begin{array}{l}1 \\
4\end{array}$ & $\begin{array}{l}16,7 \\
121\end{array}$ & $\begin{array}{c}5 \\
29\end{array}$ & $\begin{array}{l}83,3 \\
879\end{array}$ & 0,759 & 1,450 \\
\hline \multicolumn{7}{|l|}{ Status Gizi } \\
\hline KEK & 18 & 66,7 & 9 & 33,3 & \multirow{2}{*}{0,023} & \multirow{2}{*}{3,286} \\
\hline Tidak KEK & 14 & 37,8 & 23 & 62,2 & & \\
\hline \multicolumn{7}{|l|}{ Status Anemia } \\
\hline Anemia & 21 & 65,6 & 21 & 34,4 & \multirow{2}{*}{0,012} & \multirow{2}{*}{3,645} \\
\hline Tidak Anemia & 11 & 34,4 & 11 & 65,6 & & \\
\hline \multicolumn{7}{|l|}{ Satus Pre Eklampsi } \\
\hline Pre Eklampsi & 4 & 50 & 4 & 50 & \multirow{2}{*}{1,000} & \multirow{2}{*}{1,000} \\
\hline Tidak Pre Eklampsi & 28 & 50 & 28 & 50 & & \\
\hline \multicolumn{7}{|l|}{ Riwayat BBLR } \\
\hline Ada & 1 & 33,3 & 2 & 66,7 & \multirow{2}{*}{0,269} & \multirow{2}{*}{4,000} \\
\hline Tidak Ada & 4 & 11,1 & 32 & 88,9 & & \\
\hline
\end{tabular}

Dari tabel 2 tersebut dapat dilihat bahwa proporsi ibu hamil usia yang tidak beresiko lebih banyak melahirkan bayi dengan berat badan normal $(52,2 \%)$ daripada melahirkan BBLR (47,7\%). Hasil analisis uji hubungan dengan nilai $p 0,590$ menunjukkan tidak ada hubungan yang signifikan antara kejadian BBLR dengan usia ibu saat hamil. Nilai OR pada analisis kedua variabel tersebut adalah 1,339 .

Pada faktor paritas menunjukkan proporsi ibu hamil primi \& multigravida yang melahirkan BBLR lebih besar yaitu $51,7 \%$ dibandingkan yang melahirkan bayi dengan berat badan yang normal yaitu sebesar 48,3. Analisis uji hubungan antara faktor paritas dengan kejadian BBLR didapatkan nilai $p 0,672$ dan nilai OR 0,462. Nilai tersebut menunjukkan bahwa tidak terdapat hubungan yang bermakna antara Paritas dengan kejadian BBLR.

Analisis pada variabel jarak kehamilan menunjukkan proporsi ibu hamil dengan jarak kehamilan $\geq 2$ tahun lebih banyak melahirkan bayi dengan berat badan normal $(87,9 \%)$ yaitu sebesar dibandingkan melahirkan BBLR (12,1\%). Uji hubungan pada kedua variabel menunjukkan tidak ada hubungan yang berarti dengan nilai $p$ sebesar 0,759 dan nilai OR 1,450.

Hasil analisis pada variabel status gizi menunjukkan proporsi ibu hamil dengan KEK yang melahirkan BBLR (66,7\%) lebih besar dibandingkan melahirkan bayi dengan berat badan normal $(33,3 \%)$. Analisis uji hubungan dihasilkan nilai $p 0,023$ dan OR 3,286 . Ini berarti terdapat hubungan yang bermakna antara status gizi ibu hamil dengan kejadian BBLR. Ibu hamil yang mengalami KEK lebih beresiko 3,286 kali untuk melahirkan BBLR daripada ibu hamil yang tidak KEK.

Proporsi ibu hamil dengan Anemia yang melahirkan BBLR $(65,6 \%)$ lebih besar dibandingkan melahirkan bayi dengan berat badan normal (34,4\%). Analisis uji hubungan dihasilkan nilai $p 0,012$ OR 3,645 . Berarti terdapat hubungan yang 
bermakna antara anemia dalam kehamilan dengan kejadian BBLR. Ibu hamil yang mengalami Anemia lebih beresiko 3,645 kali melahirkan BBLR daripada ibu hamil yang tidak Anemia.

Pada Tabel 2 juga dapat dilihat bahwa proporsi ibu hamil yang tidak mengalami Pre Eklampsi dan melahirkan BBLR $(50,0 \%)$ sama dengan ibu hamil yang tidak Pre Eklampsi dan melahirkan bayi dengan berat badan normal $(50,0 \%)$. Tidak terdapat hubungan yang bermakna antara Pre Eklampsi dalam kehamilan dengan kejadian BBLR dengan nilai $p 1,000$.

Proporsi ibu hamil yang tidak mempunyai riwayat melahirkan BBLR lebih banyak pada responden yang melahirkan bayi dengan berat badan normal $(88,9 \%)$ dibandingkan yang melahirkan BBLR $(11,1 \%)$. Hasil uji hubungan menunjukkan tidak terdapat hubungan yang bermakna antara Riwayat BBLR dengan kejadian BBLR dengan nilai $p 0,269$ dan nilai OR 4,000 .

\section{Pembahasan}

Hasil penelitian menunjukkan bahwa terdapat hubungan yang signfikan antara status gizi dan anemia dengan kejadian BBLR. Hasil penelitian Suryati tahun 2014 juga menunjukkan hal yang sama dimana uji hubungan antara status gizi dengan BBLR didapatkan nilai $p 0,000$ dengan nilai OR 15 , 625.

Penelitian Nasreen et al (2010) menyatakan ada hubungan antara malnutrisi pada ibu hamil dengan kejadian BBLR, di mana pada penelitian tersebut status malnutrisi ibu diukur berdasarkan LILA <22 $\mathrm{cm}$ Hal ini menunjukkan bahwa ibu hamil dengan KEK mempunyai resiko lebih besar untuk melahirkan BBLR (Nasreen 2010).

Pertumbuhan dan perkembangan janin sangat dipengaruhi oleh status gizi ibu ketika hamil. Pada negara berkembang seperti Indonesia masalah gizi yang sering dihadapi oleh ibu hamil yaitu Kurang Energi Kronis (KEK). Kondisi KEK pada ibu hamil menunjukkan konsumsi energi dan protein yang kurang dalam jangka panjang. Kekurangan energi secara kronis dalam jangka waktu yang lama ini menyebabkan ibu hamil tidak memiliki cadangan gizi yang cukup untuk memenuhi kebutuhan gizi selama kehamilan. Kebutuhan energi pada trimester pertama meningkat secara minimal, kemudian terus meningkat sampai akhir kehamilan. Selama trimester ketiga tambahan energi digunakan untuk pertumbuhan janin dan placenta, jika sejak awal kehamilan ibu sudah mengalami kekurangan gizi maka kebutuhan gizi untuk pertumbuhan dan perkembangan janin terutama pada trimester ketiga tidak dapat terpenuhi sehingga berisiko untuk terjadinya BBLR (Myles, 2011).

Data Riskesdas 2013 menunjukan Prevalensi ibu hamil KEK 23,7\%, sehingga menjadi faktor risiko bagi ibu hamil untuk melahirkan BBLR. Ibu hamil KEK atau tidak, dapat dilihat dari ukuran lingkar lengan atasnya (LILA). Ukuran LILA yang normal yaitu $>23,5 \mathrm{~cm}$ dengan pengukuran menggunakan pita LILA yaitu alat yang sederhana dan praktis yang direkomendasikan oleh Kementerian Kesehatan untuk digunakan di lapangan (Kemenkes RI, 2013).

Anemia dalam kehamilan adalah kondisi dimana sel darah merah menurun atau menurunnya hemoglobin, sehingga kemampuan daya angkut oksigen untuk kebutuhan organ-organ vital ibu dan janin menjadi berkurang. Selama kehamilan indikasi anemia adalah jika konsentrasi hemoglobin kurang dari 10,50 sampai dengan 11,00 gr\% (Varney, 2007).

Menurut Manuaba (2010) anemia dalam kehamilan memberi dampak yang kurang baik bagi ibu sendiri maupun bagi kehamilan, persalinan dan nifas. Bahaya anemia bagi kehamilan antara lain dapat menimbulkan abortus, persalinan prematur, hambatan tumbuh dan kembang janin dalam uterus, mudah terkena infeksi, perdarahan antepartum maupun ketuban pecah dini (Manuaba, 2010).

Kurangnya asupan zat besi selama masa kehamilan dapat menyebabkan terjadinya anemia saat hamil yang berpengaruh secara signifikan terhadap usia kehamilan yang lebih cepat dan meningkatkan kejadian bayi lahir prematur, namun dampak buruk tersebut dapat dicegah melalui konsumsi tablet tambah darah pada masa kehamilan (Banhidy, 2011). 
Data Riskesdes 2013 menunjukkan bahwa Proporsi anemia pada ibu hamil di wailayah perkotaan sebesar 36,4\% sedangkan di wilayah pedesaan sebesar $37,8 \%$. Data itu menunjukkan tidak ada perbedaan yang berarti antara ibu hamil yang berada di perkotaan dan pedesaan (Kemenkes RI, 2013).

Ibu hamil dengan KEK dan anemia beresiko melahirkan BBLR yang jika tidak ditangani dengan baik akan beresiko mengalami stunting. Jika terjadi hal tersebut maka akan berdampak terhadap. Penurunan kualitas balita di Indonesia (Kemenkes RI, 2016).

Pencegahan BBLR tidak hanya dengan melakukan intervensi pada kehamilan. Pencegahan sebelum memasuki masa kehamilan justru dianggap lebih efektif. Pada kasus anemia misalnya, penatalaksanaan anemia yang ditemukan pada kehamilan usia lanjut lebih sulit diatasi dari pada anemia pada kehamilan usia muda. Oleh karena itu prinsip pencegahan penyebab anemia menjadi kunci penurunan angka BBLR. Artinya intervensi pada pra kehamilan juga diperlukan, misalnya pencegahan anemia dan kurang gizi pada remaja putri. Dalam hal ini keterlibatan lintas sektoral sangat diperlukan. Dinas Kesehatan dapat bekerja sama dengan Dinas Pendidikan untuk pembuatan program pencegahan anemia pada remaja putri.

\section{KESIMPULAN DAN SARAN}

Sebagian besar responden merupakan ibu yang hamil pada usia yang tidak beresiko $(68,8 \%)$, merupakan Primigravida/multigravida $90,6 \%$, dengan jarak kehamilan > 2 tahun $84,6 \%$, status gizi tidak KEK $68,6 \%$, anemia $87,5 \%$, dan tidak mempunyai riwayat BBLR $92,3 \%$.

Terdapat 4 variabel yang tidak berhubungan dengan BBLR pada penelitian ini, yaitu umur ibu (nilai p0,590), paritas (nilai p0,672 ), jarak kehamilan (nilai p0,759 ), riwayat Pre eklampsi dalam kehamilan (nilai p1,000), dan riwayat BBLR pada kehamilan sebelumnya (nilai $p 0,269$ ).

Uji hubungan didapatkan dua variabel yang berhubungan secara signifikan dengan kejadian BBLR yaitu Status Gizi dengan nilai $p 0,023$ dan variabel Riwayat Anemia dalam kehamilan dengan nilai $p 0,012$.

Institusi Pendidikan kebidanan juga dapat berkontribusi dalam peningkatan pengetahuan tentang pencegahan anemia. Bentuk kegiatan dapat dilaksanakan dalam bentuk pengabdian kepada masyarakat.

\section{REFERENSI}

Kemenkes RI. (2016). Profil Kesehatan Indonesia tahun (2015). Jakarta : Kemenkes RI

Maryunani, Anik. (2009). Asuhan Kegawatdaruratan dan Penyulit Pada Neonatus. Jakarta : TIM

Manuaba, IBG. (2010). Ilmu Kebidanan, penyakit Kandungan dan KB untuk Pendidikan Bidan Edisi 2. Jakarta:EGC

Nasreen et al .(2010). Low Birth Weight in Offspring of Women with Depressive and Anciety Symptoms During Pregnancy:Results from a Population Based Study in Bangladesh. BMC Public Health.10. Http://www.biomedcentral.com/14712458/10/515 diakses pada tanggal 6 November 2017

Myles. (2011). Buku Ajar Bidan. Jakarta : EGC

Kemenkes RI. (2013). Laporan Hasil Riset Kesehatan Dasar (Riskesdas) Indonesia tahun 2013. Jakarta :Badan Penelitian dan Pengembangan Kesehatan Kemenkes RI

Varney, H,at all. (2007). Buku Ajar Asuhan Kebidanan. Jakarta : EGC

Banhidy et al, (2011). Iron Deficiency Anemia: Pregnancy Outcomes with or without Iron Supplementation. Nutrition. 27: 65-72. Http://www.sciencedirect.com/science/ article/pii/S0899900710000031 diakses pada tanggal 6 November 2017 